\title{
Anslysis of Heavy Metal Pb, Cd Deposit in Sweet Maize Inbreds
}

\author{
Guihua Lv*, Zhenxing Wu, Guojin Guo, Jianjian Chen \\ Dongyang Maize Research Institute of Zhejiang Province, Zhejiang Academy of Agricultural Sciences, Dongyang, P. R. China \\ Email address: \\ lvgh@zaas.ac.cn (G. Lv), wuzhenxing.1991@163.com (Zhenxing Wu), guoguojin@yahoo.com.cn (Guojin Guo), \\ 181078186@qq.com (Jianjian Chen) \\ ${ }^{*}$ Corresponding author
}

\section{To cite this article:}

Guihua Lv, Zhenxing Wu, Guojin Guo, Jianjian Chen. Anslysis of Heavy Metal Pb, Cd Deposit in Sweet Maize Inbreds. Agriculture, Forestry and Fisheries. Vol. 8, No. 6, 2019, pp. 105-111. doi: 10.11648/j.aff.20190806.11

Received: August 6, 2019; Accepted: September 12, 2019; Published: October 31, 2019

\begin{abstract}
China is one of the countries with serious pollution of heavy metals in cultivated land, which caused much loss to crop yield and quality, especially to sweet maize. In order to analyze dry weight of shoots, roots and spikes and the enrichment characteristics of $\mathrm{Pb}$ and $\mathrm{Cd}$ of 10 sweet maize inbred lines under moderate $\mathrm{Pb}, \mathrm{Cd}$ and compound stress of $\mathrm{Pb}$ and $\mathrm{Cd}$ stress, a pot culture was conducted at room temperature in green house. The result indicates that the $\mathrm{Pb}$ and $\mathrm{Cd}$ accumulation in sweet maizes shows a trend like roots $>$ leaves $>$ grains. The influence of stress type on dry and fresh weight is as compound stress $>$ Cd stress $>\mathrm{Pb}$ stress. The dry and fresh weight affected by stress shows a trend as grains $>$ leaves $>$ roots. According to the yield of grains, SW10 (relative coefficient 0.964) and SW6 (relative coefficient 0.931) was selected as the Pb high tolerance inbred line and $\mathrm{Cd}$ high tolerance inbred lines respectively, and the grains' coefficients of fresh weight under compound stress are 0.706 and 0.751 respectively. 3 of 10 inbred lines are screened out, whose grains Cd accumulations are under $0.1 \mathrm{mg}$ under Cd stress. 2 of 10 inbred lines are screened out, whose grains $\mathrm{Pb}$ accumulations are under $0.1 \mathrm{mg}$ under compound stress and 3 of 10 inbred lines are screened out, whose grains Cd accumulations are under $0.1 \mathrm{mg}$ under compound stress. The inbred line SW3 is the only material whose $\mathrm{Pb}$ and $\mathrm{Cd}$ accumulations are neither exceeding the standard. Above research provides astrategy of sweet maize breeding materials under heavy metal stress.
\end{abstract}

Keywords: Heavy Metal, Pb Pollution, Cd Pollution, Sweet Maize, Deposit Character

\section{Introduction}

Heavy metal pollution is a global problem. Many countries and regions, including the United States, Japan and other developed countries, have experienced heavy metal pollution [1]. According to the statistics data, the major heavy metal pollutants discharged annually to the environment in the world are cadmium $5.0 \times 10^{6} \mathrm{t}$, lead $5.0 \times 10^{6} \mathrm{t}$, mercury $1.5 \times$ $10^{4} \mathrm{t}$ and nickel $1.0 \times 10^{6} \mathrm{t}$. These pollutants mainly come from municipal garbage, arbitrary discharge of industrial wastewater, discharge of traffic exhaust gas and the use of fertilizers and pesticides containing heavy metals, which caused serious soil pollution when these heavy metals enter the soil [2-3]. At present, the area of cadmium-contaminated soil in China has reached $2 \times 10^{5} \mathrm{~km}^{2}$, accounting for $1 / 6$ of the total cultivated land area [4]. According to the National Soil Pollution Survey Bulletin in 2014, the over-standard rate of the cultivated land in China is $19.4 \%$, of which $13.7 \%$, $2.8 \%, 1.8 \%$ and $1.1 \%$ are slightly, mildly, moderately and severely polluted, respectively. It is mainly polluted by heavy metals such as $\mathrm{Cd}, \mathrm{As}, \mathrm{Hg}, \mathrm{Pb}$ and $\mathrm{Cr}$, especially in the west south and central south areas in China are the most serious [5].

China is a big mining country. Mining areas are widely distributed in Hunan, Yunnan, Guangdong and Zhejiang provinces [6]. Lead-zinc mine is an advantageous mine in China. There are 58 lead-zinc mining areas in Zhejiang Province [7]. For a long time, due to poor capital and management, the mining environment around the mining area has been seriously affected during the mining process. At the same time, with the acceleration of urbanization and the introduction of a large number of manual manufacturing industries, the cultivated land around the city of Zhejiang Province exists. Heavy metal pollution in different degrees, 
and the phenotype of compound pollution characteristics. Tang et al., analyzed the contents of heavy metals in paddy soils in hilly areas of northern Zhejiang province. It was found that the contents of $\mathrm{Cd}$ and as in the soils of Zhejiang research area exceeded the standard obviously. From the results of heavy metals in paddy seeds, the content of cadmium exceeded the standard especially [8]. Zhu et al., took 40 counties (cities, districts) of Zhejiang Province as the research objects, and the cadmium content in soils and agricultural products was analyzed. It was found that cadmium content in soils and crops in the study area exceeded the standard to a certain extent. The exceeding standard rate of soils and crops was $10.69 \%$ and $4.57 \%$ [9].

Maize is an important food and vegetable crop in China. Heavy metal pollution has a certain impact on its yield and quality. Especially sweet and waxy maize, which is mainly fresh food, and heavy metal residues directly affect the health and safety of consumers. In coastal areas such as Zhejiang, Fujian and Guangdong, sweet maize has become an indispensable part of residents' dietary habits. At present, the research on lead and cadmium in maize mostly focuses on the selection of common maize materials and physiological and biochemical aspects. Dai et al., analyzed the enrichment ability of lead in different tissues of 22 maize varieties. It was found that there were significant differences in lead accumulation between different maize varieties and different tissues: $\operatorname{root}>$ stem $>$ leaf $>$ grain [10]. Li et al., studied the growth and lead accumulation and distribution among organs of different genotypes of maize under simulated lead stress. It was found that there were genotypic differences in lead accumulation among different genotypes of maize, but the enrichment patterns among different tissues were root $>$ leaf $>$ stem $>$ grain, and selected a high $\mathrm{Pb}$ enrichment of sweet maize varieties Shentian-1 [11]. At present, most of the studies focus on the identification of heavy metal accumulation ability of a few maize varieties, and the evaluation of heavy metal accumulation characteristics of their parents' inbred lines is not much. Jinet al., analyzed the differences of lead accumulation in 12 common maize inbred lines, and screened out many inbred lines with different accumulation characteristics, and enriched lead in maize tissues. The combining ability was also analyzed [12]. Up to now, there are few studies on heavy metal accumulation in sweet maize inbred lines. In this study, 10 certified sweet maize varieties in southeastern coastal areas were used as materials to simulate the differences and characteristics of heavy metal accumulation between genotypes and different tissues under single moderate $\mathrm{Pb}$ pollution, $\mathrm{Cd}$ pollution and $\mathrm{Pb}-\mathrm{Cd}$ combined pollution environment. In order to provide some reference for breeding safe varieties of heavy metals such as lead and cadmium in the future, materials suitable for future breeding were screened.

\section{Material and Methods}

\subsection{Material}

This research material was partially certified as parents of sweet maize varieties, provided by Crops Institute of Zhejiang Academy of Agricultural Sciences, and expressed by SW1-SW10 code.

\subsection{Methods}

\subsubsection{Test Site and Treatment}

The experiment was carried out in Greenhouse of Zhejiang Academy of Agricultural Sciences from March to August 2017. The experimental soils were collected from paddy fields in the suburbs of Dongyang City, Zhejiang Province. The heavy metals $\mathrm{Pb}, \mathrm{Cd}$ and basic physical and chemical properties of the soils were shown in Table 1. The soil samples were air-dried, ground and mixed. $\mathrm{Pb}(\mathrm{NO} 3) 2$ and $\mathrm{CdCl} 2$ were used to simulate moderate lead, cadmium and combined pollution stress intensity: control soil $\mathrm{Pb0}$ (no lead acetate was added, the actual total lead background value was $20.52 \mathrm{mg} / \mathrm{kg}$, as Normal soil control (Control), Pb400 (total lead content $400.00 \mathrm{mg} / \mathrm{kg}$, simulated moderate pollution stress), Cd 2 (total cadmium content $2.00 \mathrm{mg} / \mathrm{kg}$, simulated moderate cadmium pollution stress) and simultaneous simulation of $\mathrm{Pb} 400$ and $\mathrm{Cd} 2$ Compound pollution.

Table 1. Basic properties of soil in trial.

\begin{tabular}{lllllll}
\hline $\begin{array}{l}\text { Soil } \\
\text { properties }\end{array}$ & $\begin{array}{l}\text { pH } \\
\text { value }\end{array}$ & $\begin{array}{l}\text { Soil organic } \\
\text { matter }(\mathbf{g} / \mathbf{k g})\end{array}$ & $\begin{array}{l}\text { Availuable } \\
\text { phosphorus }(\mathbf{m g} / \mathbf{k g})\end{array}$ & $\begin{array}{l}\text { Availuable } \\
\text { potassium }(\mathbf{m g} / \mathbf{k g})\end{array}$ & $\begin{array}{l}\text { Total nitrogen } \\
\mathbf{g} / \mathbf{k g}\end{array}$ & $\begin{array}{l}\text { Pb background } \\
(\mathbf{m g} / \mathbf{k g})\end{array}$ \\
\hline & 6.13 & 33.257 & 82.35 & 233.52 & 3.31 & 29.72 \\
\hline
\end{tabular}

\subsubsection{Test Design}

The experimental glass greenhouse area was $300 \mathrm{~m}^{2}$, ventilated and illuminated evenly. Random block design was adopted: $30 \mathrm{~kg}$ of control and contaminated soil was loaded into plastic pots with diameter of $30 \mathrm{~cm}$ and height of $40 \mathrm{~cm}$. Three pots were randomly arranged with one replicate and three replicates were set up, totaling 360 pots. Sweet maize seeds were soaked for 12 hours and then germinated in a $28 \mathrm{C}$ incubator. When the seedlings grew to three leaves, seedlings with uniform size and growth were selected and transplanted into plastic pots placed in advance. Four to five seedlings were evenly planted. After the seedlings survived, three seedlings with uniform growth were retained until harvest. During the same period, water and fertilizer management was consistent. They were all cultivated according to the conventional cultivation method of sweet maize. Artificial pollination was carried out in bags at flowering stage, and samples were taken 22-25 days after pollination.

\subsubsection{Determination Method}

The root system, stem, leaf and ear of sweet maize were harvested at harvest time. Roots, stems and leaves were washed with clean water and then blanched in an oven at 105 
for 1 hour, and then dried to constant weight at $60^{\circ} \mathrm{C}$ to determine their dry matter weight, respectively. After crushing, screening and mixing, three samples were taken for heavy metal determination. The fresh ears were weighed after removing the bracts and leaves. The grains were stripped randomly with a scalpel and dried at $60^{\circ} \mathrm{C}$ to constant weight. After being blended and crushed, the grains were screened and weighed randomly for the determination of heavy metals such as $\mathrm{Pb}$ and $\mathrm{Cd}$. ICP-MS was used to determine the contents of heavy metals such as lead and cadmium, and the method of Liu Jianghui and others was used and slightly changed [13].

\subsubsection{Data Analysis}

Relative dry matter yield of roots, stems, leaves and ears was calculated, and relative coefficient (relative dry matter yield $=$ corresponding dry matter yield of each treatment/dry matter yield of control response) was calculated to evaluate the response degree of each inbred line to different polluted environment. The higher the coefficient is, the smaller the influence of heavy metal lead and cadmium pollution is. The differences of biomass, $\mathrm{Pb}$ and $\mathrm{Cd}$ contents in different genotypes of Maize under different stresses were treated by SPSS Statistics 19.0 and EXCEL 2017 software.

\section{Results and Analysis}

\subsection{Response of Different Genotypes of Sweet Maize Inbred Lines to Heavy Metal Lead, Cadmium and Combined Pollution}

The response of sweet maize inbred lines to heavy metal stress was evaluated by comparing the yield performance of underground (root), aboveground (stem and leaf) dry matter weight and fresh ear weight under different pollution environments with the corresponding yield (relative coefficient). Table 2 shows that the combined pollution of $\mathrm{Pb}$, $\mathrm{Cd}$ and $\mathrm{Pb}-\mathrm{Cd}$ has a certain effect on the dry matter yield and ear freshness of the underground and aboveground parts of sweet maize inbred lines. Relative coefficients of root, stem, leaf and ear yields were $0.932,0.937$ and 0.925 under $\mathrm{Pb}$ pollution, respectively. Relative coefficients of root, stem, leaf and ear yields were $0.896,0.858$ and 0.850 under $\mathrm{Cd}$ pollution. Under combined pollution of lead and cadmium, the relative coefficients of root, stem, leaf and ear yields were $0.763,0.719$ and 0.680 , respectively. The results showed that the combined pollution of $\mathrm{Pb}-\mathrm{Cd}$ had the greatest impact on the fresh weight of maize shoots, underground parts and ears, followed by $\mathrm{Cd}$ pollution, and the least impact was $\mathrm{Pb}$ pollution. According to the analysis of dry matter yield and relative coefficient of ear under single $\mathrm{Pb}$ pollution, there was significant difference in ear yield among inbred lines under $\mathrm{Pb}$ pollution. SW5 was the lowest, 0.815 , belonging to the lead pollution sensitive inbred line, SW10 was the highest, 0.964, and was the ear yield under Cd pollution tolerant inbred line. Among them, the relative coefficient of ear yield of SW4 and SW3 inbred lines was 0.749 and 0.801 , respectively, which could be classified as $\mathrm{Cd}$ pollution sensitive inbred lines. The relative coefficient of ear yield of SW6 was the highest and could be classified as $\mathrm{Cd}$ pollution tolerant inbred lines. The relative coefficients of ear fresh weight of Cd-polluted tolerant inbred lines SW6 and PB-polluted tolerant inbred lines SW10 were 0.751 and 0.706 respectively, ranking the first and third in the tested materials, while those of $\mathrm{Pb}$-polluted sensitive inbred lines SW5 and Cd-polluted sensitive inbred lines SW4 were the relative coefficients of ear fresh weight under $\mathrm{Pb}-\mathrm{Cd}$ combined pollution. They are 0.561 and 0.614 respectively, which are consistent with their relative sensitivity to heavy metal stress such as $\mathrm{Pb}$ and $\mathrm{Cd}$ in a single pollution environment.

Table 2. Stress response coefficient of dry matter and fresh ear yield of test self bred lines under different polluted environment.

\begin{tabular}{|c|c|c|c|}
\hline \multirow{2}{*}{$\begin{array}{l}\text { Inbred lines } \\
\text { number }\end{array}$} & \multicolumn{3}{|c|}{ Yield relative coefficient } \\
\hline & Root & Shoots & Ears \\
\hline \multicolumn{4}{|l|}{$\mathrm{Pb}$ pollution } \\
\hline SW1 & 0.943 & 0.959 & 0.930 \\
\hline SW2 & 0.958 & 0.957 & 0.947 \\
\hline SW5 & 0.956 & 0.885 & 0.815 \\
\hline SW6 & 0.915 & 0.935 & 0.934 \\
\hline SW7 & 0.916 & 0.927 & 0.907 \\
\hline SW8 & 0.870 & 0.934 & 0.943 \\
\hline SW9 & 0.888 & 0.918 & 0.914 \\
\hline SW10 & 0.936 & 0.949 & 0.964 \\
\hline Average & 0.932 & 0.937 & 0.925 \\
\hline \multicolumn{4}{|l|}{ Cd pollution } \\
\hline SW1 & 0.916 & 0.808 & 0.886 \\
\hline SW2 & 0.887 & 0.849 & 0.811 \\
\hline SW3 & 0.939 & 0.868 & 0.801 \\
\hline SW4 & 0.907 & 0.878 & 0.749 \\
\hline SW5 & 0.917 & 0.747 & 0.828 \\
\hline SW6 & 0.909 & 0.867 & 0.931 \\
\hline SW7 & 0.844 & 0.833 & 0.910 \\
\hline SW8 & 0.833 & 0.838 & 0.907 \\
\hline SW9 & 0.869 & 0.925 & 0.885 \\
\hline SW10 & 0.936 & 0.969 & 0.796 \\
\hline Average & 0.896 & 0.858 & 0.850 \\
\hline \multicolumn{4}{|c|}{$\mathrm{Pb}-\mathrm{Cd}$ pollution } \\
\hline SW1 & 0.831 & 0.751 & 0.695 \\
\hline SW2 & 0.807 & 0.774 & 0.675 \\
\hline SW3 & 0.806 & 0.715 & 0.687 \\
\hline SW4 & 0.768 & 0.713 & 0.614 \\
\hline SW5 & 0.637 & 0.593 & 0.561 \\
\hline SW6 & 0.793 & 0.719 & 0.751 \\
\hline SW7 & 0.753 & 0.604 & 0.750 \\
\hline SW8 & 0.701 & 0.647 & 0.684 \\
\hline SW9 & 0.736 & 0.799 & 0.678 \\
\hline SW10 & 0.796 & 0.876 & 0.706 \\
\hline Average & 0.763 & 0.719 & \\
\hline
\end{tabular}

\subsection{Characteristics of Lead Accumulation in Different Tissues of Different Genotypes of Sweet Maize Under Single Lead Pollution}

Variance analysis showed that under the single lead pollution environment, the lead content in different tissues of 10 inbred lines was significantly different, showing the rule of root $>$ stem and leaf $>$ grain. The lead content in roots, stems and leaves of most genotypes showed significant differences except for the level of grain among the same parts of inbred lines. Table 3 shows that root lead content of genotype SW5 
and SW8 are $262.384 \mathrm{mg} / \mathrm{kg}$ and $259.193 \mathrm{mg} / \mathrm{kg}$ respectively, which have higher enrichment coefficient, while root lead content of genotype SW9 is the lowest, $168.103 \mathrm{mg} / \mathrm{kg}$ has lower root enrichment coefficient, so there are significant differences among genotypes, among which genotype SW5 is the highest. The lead content in stems and leaves of genotype SW3 was the lowest at $124.246 \mathrm{mg} / \mathrm{kg}$, which was $87.759 \mathrm{mg} / \mathrm{kg}$. The lead content in grains of most genotypes (SW1 and SW6 with the same lead content in grains) was significantly different, but the lead content of the tested genes exceeded the national stipulated value of $0.1 \mathrm{mg} / \mathrm{kg}$, which had a certain safety risk. Among them, genotype SW8 had the highest content $(0.419 \mathrm{mg} / \mathrm{kg})$, more than four times the national standard value, while SW3 had the lowest content $(0.145 \mathrm{mg} / \mathrm{kg})$.

Table 3. Pb content of different tissues and sweet inbredlines under Single $\mathrm{Pb}$ pollution.

\begin{tabular}{llll}
\hline Genotypes & $\begin{array}{l}\text { Pb content in } \\
\text { roots }(\mathbf{m g} / \mathbf{k g})\end{array}$ & $\begin{array}{l}\text { Pb content in } \\
\text { shoots }(\mathbf{m g} / \mathbf{k g})\end{array}$ & $\begin{array}{l}\text { Pb content in } \\
\text { grains }(\mathbf{m g} / \mathbf{k g})\end{array}$ \\
\hline Pb & & & \\
\hline SW1 & $242.871 \pm 1.223 \mathrm{~d}$ & $91.631 \pm 1.201 \mathrm{e}$ & $0.322 \pm 0.009 \mathrm{e}$ \\
SW2 & $214.012 \pm 1.203 \mathrm{f}$ & $88.438 \pm 1.072 \mathrm{i}$ & $0.254 \pm 0.008 \mathrm{f}$ \\
SW3 & $186.403 \pm 2.400 \mathrm{~g}$ & $87.759 \pm 1.102 \mathrm{j}$ & $0.145 \pm 0.008 \mathrm{i}$ \\
SW4 & $232.493 \pm 2.432 \mathrm{e}$ & $89.495 \pm 0.946 \mathrm{~g}$ & $0.243 \pm 0.009 \mathrm{a}$ \\
SW5 & $262.384 \pm 3.331 \mathrm{a}$ & $124.246 \pm 2.223 \mathrm{a}$ & $0.372 \pm 0.010 \mathrm{c}$ \\
SW6 & $250.945 \pm 1.948 \mathrm{~b}$ & $117.910 \pm 1.405 \mathrm{~b}$ & $0.323 \pm 0.012 \mathrm{e}$ \\
SW7 & $247.246 \pm 2.902 \mathrm{c}$ & $91.723 \pm 1.205 \mathrm{~d}$ & $0.237 \pm 0.007 \mathrm{~g}$ \\
SW8 & $259.193 \pm 1.254 \mathrm{a}$ & $113.485 \pm 1.303 \mathrm{c}$ & $0.419 \pm 0.008 \mathrm{~b}$ \\
SW9 & $168.103 \pm 3.401 \mathrm{~h}$ & $88.786 \pm 0.998 \mathrm{~h}$ & $0.171 \pm 0.009 \mathrm{~h}$ \\
SW10 & $183.794 \pm 2.900 \mathrm{~g}$ & $90.768 \pm 2.690 \mathrm{f}$ & $0.342 \pm 0.008 \mathrm{~d}$ \\
F value & $126.78 * *$ & $36.23 * *$ & $2.78 *$ \\
\hline
\end{tabular}

Note: Data in the table is the average and standard error derived from three replicates. The different letter means significant difference at 0.05 level between different genotypes under the same pollution level. *indicates $\mathrm{P}<0.05$; **indicates $\mathrm{P}<0.01$, the same below.

\subsection{Lead Accumulation Characteristics in Different Tissue Parts of Different Genotypes of Sweet Maize Under Single Cadmium Pollution}

Table 4 shows that the cadmium contents in roots, stems and grains of 10 tested materials are significantly different, showing the accumulation characteristics of roots $>$ stems and leaves $>$ grains. There were also significant differences in cadmium content among genotypes in the same tissue. Among them, SW1 $(3.672 \mathrm{mg} / \mathrm{kg})$ had the highest cadmium content in roots, SW9 $(1.309 \mathrm{mg} / \mathrm{kg})$ had the lowest, SW3 $(2.012 \mathrm{mg} / \mathrm{kg})$ had the highest cadmium content in stems and leaves, SW1 $(0.313 \mathrm{mg} / \mathrm{kg})$ had the highest cadmium content in grains and SW9 $(0.063 \mathrm{mg} / \mathrm{kg})$ had the lowest cadmium content. Among the 10 tested materials, three genotypes had no $\mathrm{Cd}$ content exceeding the national standard $(0.1 \mathrm{mg} / \mathrm{kg})$, which were SW5 $(0.096 \mathrm{mg} / \mathrm{kg})$, SW6 $(0.087 \mathrm{mg} / \mathrm{kg})$ and SW9 $(0.063 \mathrm{mg} / \mathrm{kg})$, respectively. These materials had potential value for safe variety utilization.

Table 4. Cd content of different tissues and sweet inbredlines under Single Cd pollution.

\begin{tabular}{llll}
\hline Genotypes & $\begin{array}{l}\text { Cd content in } \\
\text { roots }(\mathbf{m g} / \mathbf{k g})\end{array}$ & $\begin{array}{l}\text { Cd content in } \\
\text { shoots }(\mathbf{m g} / \mathbf{k g})\end{array}$ & $\begin{array}{l}\text { Cd content in } \\
\text { grains }(\mathbf{m g} / \mathbf{k g})\end{array}$ \\
\hline Cd & & & \\
\hline SW1 & $3.672 \pm 0.2023 \mathrm{a}$ & $1.813 \pm 0.1123 \mathrm{c}$ & $0.313 \pm 0.0212 \mathrm{c}$ \\
SW2 & $2.823 \pm 0.2233 \mathrm{~d}$ & $1.184 \pm 0.1234 \mathrm{f}$ & $0.171 \pm 0.0201 \mathrm{e}$ \\
SW3 & $3.224 \pm 0.1225 \mathrm{~b}$ & $2.012 \pm 0.0956 \mathrm{a}$ & $0.253 \pm 0.0165 \mathrm{a}$ \\
SW4 & $1.955 \pm 0.2343 \mathrm{~g}$ & $1.037 \pm 0.1906 \mathrm{~g}$ & $0.116 \pm 0.0253 \mathrm{f}$ \\
SW5 & $1.431 \pm 0.1447 \mathrm{i}$ & $0.980 \pm 0.1445 \mathrm{i}$ & $0.096 \pm 0.0011 \mathrm{~g}$ \\
SW6 & $2.667 \pm 0.2389 \mathrm{e}$ & $1.331 \pm 0.1467 \mathrm{e}$ & $0.087 \pm 0.0025 \mathrm{~h}$ \\
SW7 & $3.031 \pm 0.2367 \mathrm{c}$ & $1.922 \pm 0.1589 \mathrm{~b}$ & $0.224 \pm 0.0012 \mathrm{~b}$ \\
SW8 & $2.225 \pm 0.2354 \mathrm{f}$ & $1.431 \pm 0.0890 \mathrm{~d}$ & $0.189 \pm 0.0019 \mathrm{~d}$ \\
SW9 & $1.309 \pm 0.18 \mathrm{j}$ & $0.786 \pm 0.12 \mathrm{j}$ & $0.063 \pm 0.0019 \mathrm{i}$ \\
SW10 & $1.709 \pm 0.23 \mathrm{~h}$ & $1.045 \pm 0.11 \mathrm{~h}$ & $0.215 \pm 0.0024 \mathrm{c}$ \\
F value & $4.29 * *$ & $3.12 * *$ & $2.05 * *$ \\
\hline
\end{tabular}

\subsection{Accumulation Characteristics of Lead and Cadmium in Different Tissue Parts of Sweet Maize Under Lead-Cadmium Compound Pollution Environment}

Table 5 shows that the differences of lead and cadmium contents among different genotypes in roots, stems and leaves, grains are very significant except for individual phenotypes. It shows that the accumulation of lead and cadmium is different among different genotypes under the combined pollution environment, and the accumulation of lead and cadmium is different among different tissues. The accumulation showed the characteristics of $\operatorname{root}>$ stem and leaf $>$ grain, which was consistent with the phenotype under single pollution. Under the combined pollution of lead and cadmium, the highest lead accumulation was SW8 $(246.653 \mathrm{mg} / \mathrm{kg})$ and the lowest was SW9 $(160.381 \mathrm{mg} / \mathrm{kg})$. The highest accumulation of lead in stems and leaves was SW6 $(121.251 \mathrm{mg} / \mathrm{kg})$, the lowest was SW10 $(86.861 \mathrm{mg} / \mathrm{kg})$, the highest was SW8 $(0.473 \mathrm{mg} / \mathrm{kg})$ in grains, the lowest was SW3 $(0.082 \mathrm{mg} / \mathrm{kg})$, the highest accumulation of cadmium in roots was SW3 $(3.048 \mathrm{mg} / \mathrm{kg})$, and the lowest was SW9 $(1.222 \mathrm{mg} / \mathrm{kg})$. The highest cadmium accumulation in stems and leaves was SW3 $(1.765 \mathrm{mg} / \mathrm{kg})$, and the lowest was SW9 $(0.536 \mathrm{mg} / \mathrm{kg})$. The highest Cd content was SW1 $(0.365 \mathrm{mg} / \mathrm{kg})$ and the lowest was SW9 $(0.064 \mathrm{mg} / \mathrm{kg})$. The accumulation characteristics of lead and cadmium in different genotypes and tissues of maize were not significantly correlated. Finally, two inbred lines were screened with lead and cadmium content in grains as indicators. They were SW3 and SW9, respectively. Three inbred lines with cadmium content in grains were SW4, SW5 and SW9, respectively. The contents of lead and cadmium in grains of SW9 were not exceeded under the combined pollution of heavy metal lead and cadmium.

Table 5. $\mathrm{Pb}$ and $\mathrm{Cd}$ content in different tissues of sweet inbred lines under counpound $\mathrm{Pb}$-Cd pollution.

\begin{tabular}{llllll}
\hline \multirow{2}{*}{ Material } & \multicolumn{2}{l}{ Heavy metal content in roots (mg/kg) } & \multicolumn{2}{l}{ Heavy metal content in shoots (mg/kg) } & \multicolumn{2}{l}{ Heavy metal content in grains (mg/kg) } \\
\cline { 2 - 6 } & Pb & Cd & Pb & Cd & Pb \\
\hline SW1 & $226.482 \pm 2.242 \mathrm{e}$ & $2.982 \pm 0.131 \mathrm{c}$ & $95.530 \pm 2.121 \mathrm{~d}$ & $1.230 \pm 0.124 \mathrm{c}$ & $0.431 \pm 0.021 \mathrm{e}$ \\
SW2 & $219.533 \pm 4.753 \mathrm{~g}$ & $2.604 \pm 0.223 \mathrm{~d}$ & $94.043 \pm 1.852 \mathrm{f}$ & $0.934 \pm 0.117 \mathrm{e}$ & $0.390 \pm 0.023 \mathrm{f}$ \\
SW3 & $168.643 \pm 3.712 \mathrm{i}$ & $3.048 \pm 0.172 \mathrm{a}$ & $87.663 \pm 1.571 \mathrm{~g}$ & $1.765 \pm 0.181 \mathrm{a}$ & $0.082 \pm 0.037 \mathrm{i}$ \\
\hline
\end{tabular}




\begin{tabular}{llllll}
\hline \multirow{2}{*}{ Material } & \multicolumn{2}{l}{ Heavy metal content in roots (mg/kg) } & \multicolumn{2}{l}{ Heavy metal content in shoots (mg/kg) } & \multicolumn{2}{l}{ Heavy metal content in grains (mg/kg) } \\
\cline { 2 - 6 } & Pb & Cd & Pb & Cd & Pb \\
\hline SW4 & $220.826 \pm 2.624 \mathrm{f}$ & $1.921 \pm 0.338 \mathrm{~g}$ & $95.320 \pm 1.191 \mathrm{e}$ & $0.898 \pm 0.137 \mathrm{f}$ & $0.311 \pm 0.013 \mathrm{f}$ \\
SW5 & $235.536 \pm 4.742 \mathrm{~b}$ & $1.264 \pm 0.228 \mathrm{i}$ & $116.544 \pm 1.427 \mathrm{~b}$ & $0.817 \pm 0.112 \mathrm{~g}$ & $0.438 \pm 0.018 \mathrm{a}$ \\
SW6 & $229.211 \pm 3.506 \mathrm{c}$ & $2.416 \pm 0.122 \mathrm{e}$ & $121.251 \pm 1.213 \mathrm{a}$ & $1.201 \pm 0.121 \mathrm{c}$ & $0.461 \pm 0.025 \mathrm{c}$ \\
SW7 & $227.455 \pm 2.141 \mathrm{~d}$ & $3.040 \pm 0.157 \mathrm{~b}$ & $79.543 \pm 2.117 \mathrm{i}$ & $1.553 \pm 0.153 \mathrm{~b}$ & $0.383 \pm 0.033 \mathrm{~b}$ \\
SW8 & $246.653 \pm 2.712 \mathrm{a}$ & $1.951 \pm 0.154 \mathrm{f}$ & $111.020 \pm 1.508 \mathrm{c}$ & $1.168 \pm 0.214 \mathrm{~d}$ & $0.025 \mathrm{f}$ \\
SW9 & $160.381 \pm 3.543 \mathrm{j}$ & $1.222 \pm 0.223 \mathrm{j}$ & $94.035 \pm 1.417 \mathrm{f}$ & $0.536 \pm 0.276 \mathrm{i}$ & $0.095 \pm 0.019 \mathrm{~g}$ \\
SW10 & $197.039 \pm 1.963 \mathrm{~h}$ & $1.418 \pm 0.136 \mathrm{~h}$ & $86.861 \pm 1.322 \mathrm{~h}$ & $0.859 \pm 0.122 \mathrm{~h}$ & $0.246 \pm 0.033 \mathrm{~g}$ \\
F value & $28.86^{* *}$ & $4.58^{* *}$ & $3.23 * *$ & $0.017 \mathrm{~d}$ & $0.064 \pm 0.019 \mathrm{~h}$ \\
\hline
\end{tabular}

\subsection{Interaction of Lead and Cadmium Accumulation in Different Genotypes and Tissues Under Lead-Cadmium Compound Pollution Environment}

Table 6 and correlation analysis showed that under single lead and cadmium pollution and combined lead-cadmium pollution, the contents of lead and cadmium in sweet maize inbred lines were positively correlated with the contents of lead and cadmium in roots, stems and leaves. There were significant differences in root and grain lead contents under single lead pollution and compound pollution, but there was no significant difference in stem and leaf lead contents between the two environments. There were significant differences in root cadmium content and stem and leaf cadmium content under single cadmium pollution, but there was no difference in grain cadmium content. Significant. The contents of lead and cadmium in roots under single lead and cadmium pollution were significantly lower than those under combined pollution, and the cadmium content in stems and leaves under single cadmium pollution was significantly higher than that under combined pollution.

Table 6. Comparison of $\mathrm{Pb}$ and $\mathrm{Cd}$ content in different tissues under counpound $\mathrm{Pb}-\mathrm{Cd}$ pollution.

\begin{tabular}{llll}
\hline Pollution environment & Roots & Shoots & Grains \\
\hline $\mathrm{Pb}$ & $224.77 \mathrm{a}$ & $98.41 \mathrm{c}$ & $0.31 \mathrm{~d}$ \\
$\mathrm{~Pb}(\mathrm{~Pb}-\mathrm{Cd})$ & $213.19 \mathrm{~b}$ & $98.17 \mathrm{c}$ & $0.40 \mathrm{e}$ \\
$\mathrm{Cd}$ & $2.41 \mathrm{~A}$ & $1.36 \mathrm{C}$ & $0.16 \mathrm{E}$ \\
$\mathrm{Cd}(\mathrm{Pb}-\mathrm{Cd})$ & $2.18 \mathrm{~B}$ & $1.09 \mathrm{D}$ & $0.16 \mathrm{E}$ \\
\hline
\end{tabular}

\section{Discussion}

\subsection{Screening and Evaluation of Safe Varieties Contaminated by Heavy Metals}

Heavy metal pollution control is an important part of cultivated land pollution control in China. Traditional bioremediation methods using highly enriched plants as a means are difficult to be widely applied in China due to their low biomass, long repair period, poor ecological adaptability and low economic value [14]. As early as the 1980s, Baker pointed out that polluting a different plant means that the plant's upper part of the pollutant content can be kept at a low level under a certain range of pollutant concentrations [15], and then researchers have proposed pollution countermeasures. The concept of Polling-Safe-Cultivar (PSC), that is, when planted under certain pollution conditions, the edible metal content of the edible parts meets the national safety standards [16], but the concept is only from the edible part content standard to safety. Varieties were required, but there was no specific regulation on the yield performance of these varieties on heavy metal-contaminated cultivated land. A large number of studies have shown that the effects of heavy metal lead and cadmium pollution on crops run through the life of crops, and ultimately affect crop yield and quality. Heavy metal stress can affect seed germination [17], destroy chloroplast structure, affect chlorophyll synthesis [18], intensify the increase of reactive oxygen species in vivo, inhibit plant photosynthesis, and ultimately affect crop biomass [19]. For example, with the increase of soil $\mathrm{Cd}$ pollution concentration, the yield of spring wheat showed a downward trend. When the concentration of $\mathrm{Cd}$ pollution was $10.86 \mathrm{mg} \cdot \mathrm{kg}^{-1}$, the yield of wheat decreased by $10 \%$ [20]. Previous studies on the selection of safe maize varieties or their parents mostly only considered the content of heavy metals in their grains, and the evaluation of their biomass and grain yield was not much. For example, Wu Chuanxing et al. screened 23 maize cultivars for low accumulation of heavy metals based on the contents of $\mathrm{As}, \mathrm{Hg}, \mathrm{Cu}, \mathrm{Zn}, \mathrm{Cd}, \mathrm{Cr}$ and $\mathrm{Pb}$ in grains under the background value of heavy metals in soil, and 18 varieties with low accumulation of heavy metals were obtained [21]. It is incomplete to judge whether a variety is safe from the accumulation of heavy metals in grains. The safe varieties of heavy metals should grow normally on the cultivated land polluted by certain heavy metals, maintain a certain yield level, and be able to meet the national standard of heavy metals compound in edible parts. This study simulated the yield level and grain heavy metal content of sweet maize inbred lines under moderate heavy metal lead, cadmium and lead-cadmium combined pollution. The response of tested materials to lead, cadmium and combined pollution was measured by dry matter or yield performance of different tissues. The content of heavy metal lead and cadmium in grains at the optimum harvest time was used to evaluate the test materials. The enrichment characteristics of heavy metals in the materials have screened out excellent materials for breeding of countermeasures against lead and cadmium pollution.

\subsection{Accumulation Characteristics of Heavy Metals Lead and Cadmium in Tissues of Sweet Maize Inbred Lines}

It is an indisputable fact that the accumulation of heavy metals is different among different crops. Wang Xin et al. showed that the $\mathrm{Cd}$ content in grains was wheat $>$ rice $>$ soybean $>$ maize, indicating that maize was a low 
accumulation crop of heavy metals [22]. The accumulation of heavy metals in crops showed not only interspecific differences, but also intraspecific differences [23], which were found in rice [24], barley [25], peanut [26] and sunflower [27]. Different maize varieties also had different accumulation and resistance to heavy metals. Li Junmei et al. analyzed morphological indexes such as root length, fresh root weight, chlorophyll content, POD and SOD activity of three maize varieties under cadmium pollution by hydroponic method, and revealed that there were significant differences in accumulation and resistance among different genotypes of maize [28]. In this study, the accumulation of lead and cadmium in different tissues of Maize under single lead pollution, single cadmium pollution and combined lead and cadmium pollution showed the characteristics of root $>$ stem and leaf $>$ grain, which was consistent with the identification conclusion of previous maize hybrids and inbred lines. It shows that sweet maize also follows this rule. The evaluation of heavy metal accumulation ability of inbred lines in common maize has been used to guide breeding practice. Wen Qiuhong et al. used six maize inbred lines in contaminated soil to study the cadmium accumulation ability of maize inbred lines and the optimum harvest time. The results showed that different maize inbred lines had significant genotypes for heavy metal accumulation. The possibility of breeding cadmium-safe Maize Varieties by using inbred lines tolerant to cadmium and low accumulation of cadmium was also prospected [29]. Jinfeng et al. screened 12 maize inbred lines for lead accumulation and matched diallel crosses, and systematically put forward common maize breeding strategies for different levels of lead pollution [11]. Zhang et al. evaluated the accumulation of lead and cadmium in 19 inbred lines commonly used in Southwest China, and screened out low-lead and low-cadmium accumulation inbred lines such as S37 and ES40 [30]. At present, there are few studies on Evaluation of heavy metal accumulation in sweet maize inbred lines. In this study, the accumulation characteristics of heavy metal lead and cadmium in different tissues of 10 sweet maize inbred lines under single lead pollution, single cadmium pollution and combined lead and cadmium pollution were analyzed. Under single cadmium pollution environment, low cadmium accumulation materials in grains were obtained. Three inbred lines with low accumulation of lead and 3 inbred lines with low accumulation of cadmium were obtained under compound pollution environment. Among them, the content of lead and cadmium in grains did not exceed the standard one under compound pollution. The acquisition of these materials could provide a certain material basis for future breeding of sweet maize for countermeasure of heavy metal lead and cadmium pollution.

\section{Conclusion}

In this study, ten sweet corn inbred lines were evaluated for lead and cadmium accumulation, and the inbred lines with different accumulation of lead and cadmium were screened, and the accumulation trend of lead and cadmium in different tissues was analyzed. At the same time, it was found that there was no obvious correlation between lead and cadmium accumulation in sweet corn. It was speculated that the accumulation of lead and cadmium was determined by different regulatory mechanisms.

\section{Author Contributions}

Guihua Lv. and Guojin Guo planed and supervised the experiments. Zhenxing $\mathrm{Wu}$, Jianjian Chen conducted the experiment and analyzed the results. Guihua Lv wrote the first draft of the manuscript. All authors contributed to interpretation of results and reviewed the manuscript.

\section{Acknowledgements}

This work was financially supported by Major Agriculture Science Foundation of Upland Grain Crop Breeding of Zhejiang Province (grant No. 2016C2050-9-1) and Maize Breeding Support Discipline of Zhejiang Academy of Agricultural Sciences (10102000318CC1601G/018).

\section{References}

[1] Zhao M W, Ta L, Li P. Research on heavy metal pollution to soil and countermeasures on prevention and restoration $[\mathrm{J}]$. Environmental Science and Management, 2007, 32 (6): 70-72.

[2] Shao Y, Hao Z Z, Wang W F, et al. Research progress on heavy metal contaminated soils and research advances in remediation technology [J]. Northern Horticulture. 2016 (17): 193-196.

[3] Chen J, Lin Z J, Meng Y Y, et al. Research progress on phytoremediation for heavy metal contamination in soil and hyperaccumulators [J]. Journal of the Environmental Management College of China, 2011, 21 (1): 69-71.

[4] Li J, Zhou Y W, Chen S, et al. Actualities, damage and management of soil cadmium pollution in China [J]. Anhui Agricultural Science Bulletin, 2015, 21 (24): 104-107.

[5] Shi Q L. Leaching character of $\mathrm{Pb}$ and $\mathrm{Cd}$ in the contaminated soils by organic chelating agents and biosurfactant [D]. Southwest University, 2015.

[6] Chang Q S, Ma X Q, Wang Z Y. Pollution characteristics of heavy metals and their pollution evalution in the heavy metal mining areas in south China $[\mathrm{J}]$. Resources and Environment in the Yangtze Basin, 2007, 16 (3): 395-399.

[7] Pan S M. Geology and mineral records of Zhejiang province [M]. Beijing: Local Records Press, 2003: 193-196.

[8] Tang D D, Yuan X Y, Wang Y M, et al. Enrichment characteristics and risk prediction of heavy metals for rice grains growing in paddy soils with a high geological background [J]. Journal of Agro-Environment Science, 2018, 37 (1): 18-26.

[9] Zhu Y W, Duan L L, Zhou Y, et al. Spatial pattern and interrelation of total cd in soils and crops across the agricultural regions of Zhejiang province, China [J]. Journal of Agricultural Resources and Environment, 2014, (1): 79-84. 
[10] Dai Q L, Yuan J G, Fang W. et al. Differences of $\mathrm{Pb}$ accumulation among plant tissues of 25 Zea mays varieties [J]. Acta Phytoecologica Sinica, 2005, 29 (6): 992-999.

[11] Li Y F, Liu L, Chen X, et al. Plant growth, lead uptake and partitioning of maize (Zea mays L.) under simulated mild/moderate lead pollution stress [J]. Journal of Agro-Environment Science, 2010, 29 (12): 2260-2267.

[12] Jing $\mathrm{F} . \mathrm{Pb}$ resistance and genetic effects of $\mathrm{Pb}$ accumulation in maize inbred lines [D]. Sichuan Agricultural University, 2010.

[13] Liu J H, Zhou H. Simultaneous determination of 8 trace toxic elements in food by ICP-MS [J]. Chinese Journal of Health Laboratory Technology, 2004 (1): 3-4+2.

[14] Qian C X, Wang M M, Xu Y B. Current situation of soil contamination by heavy metals and research progress in bio-remediation technique [J]. Journal of Southeast University (Natural Science Edition), 2013, 43 (3): 669-674.

[15] Baker A J M. Accumulators and Excluders-Strategies in the response of plants to heavy metals [J]. Journal of Plant Nutrition, 1981, 3 (1-4): 643-654.

[16] Yu H, Wang J L, Fang W, et al. Cadmium accumulation in different rice cultivars and screening for pollution-safe cultivars of rice $[\mathrm{J}]$. Science of the Total Environment, 2006, $370(2-3)$ : 302-309.

[17] Zhang Y X. The Toxic Effects of Mercury, Cadmium and Lead to Brasica chinesis L. [J] Journal of Shanxi University (Natural Science Edition), 2004, 27 (4): 410-413.

[18] Li Y M. Biological effects of nitrogen application on pakchoi grown on cadmium-contaminated loessial soil [D]. Northwest A\&F University, 2008.

[19] Li L J. Zheng P S, Xie S J. Effect of cadmium on maize seeds germination and growth [J]. Journal of Shanxi University, 2001, 24 (1): 93-94.

[20] Hong R Y, Yang G X, Liu D H. et al. PEffects of cadmium on the growth and physiological and biochemical reactions of wheat seedlings [J]. Acta Agriculturae Boreali Sinica, 1991, 6 (3): 70-75.

[21] $\mathrm{Wu} \mathrm{C} \mathrm{X}, \mathrm{Wu} J$, Yang G, et al. Screening of maize varieties with low accumulation of heavy metals [C] //National symposium on agricultural environmental science. 2009.

[22] Wang X, Wu Y Y. Study on the absorption characteristics of heavy metal compound pollution by different crops [J]. Agro-environmental Protection, 1998, 17 (5): 193-196.

[23] Grant C A, Clarke J M, Duguid S, et a1. Selection and breeding of plant cultivars tominimize cadmium accumulation [J]. Science of the Total Environment, 2008, 390 (2): 301-310.

[24] Li Z W, Zhang Y L, Pan G X, et a1. Grain contents of Cd, Cu and Se by 57 rice cultivars and the risk significance for human dietary uptake [J]. Chinese Journal of Environmental Science, 2003, 24 (3): 112-115.

[25] Wu F B, Zhang G. Genotypic differences in effect of Cd on growth and mineral concentrations in barley seedlings [J]. Bulletin of Environmental Contamination and Toxicology, 2002, 69 (2): 219.

[26] Mclaughlin M J, Bell M J, Wright G C, et al. Uptake and partitioning of cadmium by cultivars of peanut (Arachis hypogaea L.) [J]. Plant and Soil, 2000, 222 (1-2): 51-58.

[27] Li Y M, Chaney R L, Schneiter A A, et al. Screening for low grain cadmium phenotypes in sunflower, durum wheat and flax [J]. Euphytica, 1997, 94 (1): 23-30.

[28] Li J M, Wang H X. Eco-physiological Responses and Resistance to Cadmium Stress in Three Varieties of Maize [J]. Journal of Yunnan University (Natural Sciences Edition), 2000, 22 (4) 311-317.

[29] Wen Q H, Yu L H. The ability of accumulate Cadmium and the best harvest time of six series maize inbred lines in $\mathrm{Cd}$ contaminated soil [j]. Acta Ecologica Sinica, 2006, 26 (12): 4066-4070.

[30] Zhang $\mathrm{Z}$, Jin F, Wang $\mathrm{C}$, et al. Difference between $\mathrm{Pb}$ and $\mathrm{Cd}$ accumulation in 19 elite maize inbred lines and application prospects [J]. Journal of Biomedicine and Biotechnology, 2015, 2012 (1): 271485.

\section{Biography}

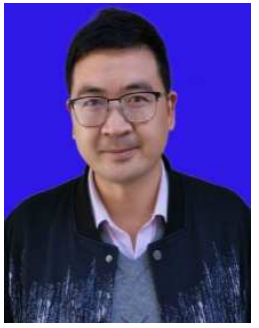

Guihua Lv, male, 37, with master's degree. $\mathrm{He}$ is the deputy director of Dongyang Corn Research Institute, Zhejiang Province. He is mainly engaged in the breeding and demonstration of new sweet and waxy corn varieties. He has also been responsible for the breeding of many new fresh-eating corn varieties in China. He has published more than 10 papers in journals such as Chinese Agricultural Science and Horticulture, and has hosted more than 20 scientific research projects.

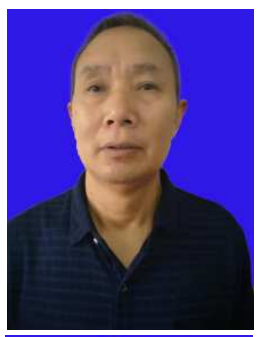

Zhenxing Wu, 28 years old, graduate student, major in crop genetics and breeding, mainly engaged in fresh corn breeding and promotion.

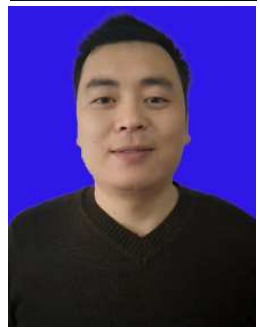

Guojin Guo, 57 years old, associate researcher, major in agriculture, mainly engaged in fresh corn breeding and promotion, data investigation and review in this paper.

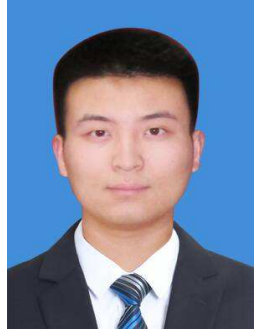

Jianjian Chen, 36 years old, associate researcher, major in crop genetics and breeding, mainly engaged in fresh corn breeding and promotion, data analysis and editing in this paper. 